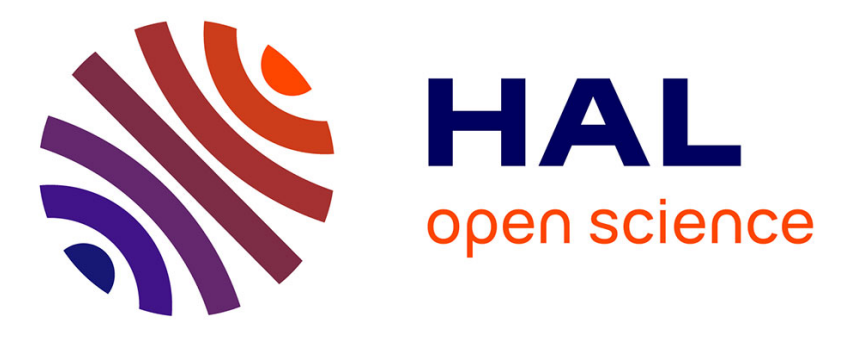

\title{
Serum club cell protein 16 is associated with asymptomatic airway responsiveness in adults: Findings from the French epidemiological study on the genetics and environment of asthma
}

Marta Rava, Nicole Le Moual, Xavier Dumont, Stefano Guerra, Valerie Siroux, Bénédicte Jacquemin, Francine Kauffmann, Alfred Bernard, Rachel Nadif

\section{To cite this version:}

Marta Rava, Nicole Le Moual, Xavier Dumont, Stefano Guerra, Valerie Siroux, et al.. Serum club cell protein 16 is associated with asymptomatic airway responsiveness in adults: Findings from the French epidemiological study on the genetics and environment of asthma. Respirology, 2015, 20 (8), pp.1198-205. 10.1111/resp.12609 . inserm-01353995

\section{HAL Id: inserm-01353995 https://www.hal.inserm.fr/inserm-01353995}

Submitted on 16 Aug 2016

HAL is a multi-disciplinary open access archive for the deposit and dissemination of scientific research documents, whether they are published or not. The documents may come from teaching and research institutions in France or abroad, or from public or private research centers.
L'archive ouverte pluridisciplinaire HAL, est destinée au dépôt et à la diffusion de documents scientifiques de niveau recherche, publiés ou non, émanant des établissements d'enseignement et de recherche français ou étrangers, des laboratoires publics ou privés. 
Serum CC-16 level is associated with asymptomatic airway responsiveness in adults from the EGEA study

Marta Rava, $\mathrm{PhD}^{1,2}$, Nicole Le Moual, $\mathrm{PhD}^{1,2}$, Xavier Dumont ${ }^{3}$, Stefano Guerra ${ }^{4,5}$, Valerie Siroux $^{6,7,8}$, Benedicte Jacquemin ${ }^{1,2,4}$, Francine Kauffmann ${ }^{1,2}$, Alfred Bernard ${ }^{3}$, Rachel Nadif ${ }^{1,2}$

1. INSERM, VIMA: Aging and chronic diseases. Epidemiological and public health approaches, U1168, F-94807, Villejuif, France

2. Univ. Versailles St-Quentin-en-Yvelines, UMR-S 1168, France

3. Louvain Centre for Toxicology and Applied Pharmacology (LTAP), Catholic University of Louvain, Tour Pasteur, avenue E. Mounier, 53- box B1-52-12, 1200 Brussels, Belgium

4. Centre for Research in Environmental Epidemiology (CREAL), IMIM-Hospital del Mar, CIBERESP, Carrer del Doctor Aiguader, 88, 08003 Barcelona

5. Arizona Respiratory Center, University of Arizona, 1501 N. Campbell Ave., Suite 2349, PO Box 245030 Tucson, AZ

6. Univ. Grenoble Alpes, IAB, Team of Environmental Epidemiology applied to Reproduction and Respiratory Health, F-38000 Grenoble, France.

7. INSERM, IAB, Team of Environmental Epidemiology applied to Reproduction and Respiratory Health, F-38000 Grenoble, France.

8. CHU de Grenoble, IAB, Team of Environmental Epidemiology applied to Reproduction and Respiratory Health, F-38000 Grenoble, France.

9. INSERM, U823, Institut Albert Bonniot, Rond-point de la Chantourne, 38706 La Tronche, France

\section{Corresponding author:}

Marta RAVA, $\mathrm{PhD}$ 
Current contact information:

Genetic \& Molecular Epidemiology Group

Human Cancer Genetics Program

Spanish National Cancer Research Centre -

Centro Nacional de Investigaciones Oncológicas (CNIO)

Melchor Fernández Almagro, 3

28029-Madrid, Spain

Tel +34 912246900 (3332)

Fax +34912246980

e-mail:mrava@cnio.es

MR, RN, NLM, BJ, FK and VS participated in study design and data collection. AB and XD performed the measurement. MR, NLM, FK, SG and VS interpreted the data. MR and RN drafted the manuscript with input from the other authors. All the authors revised the article critically for important intellectual content and approved the final manuscript.

Abstract's words count: 248

Manuscript's words count: 2500 


\title{
Summary at a glance (less than 50 words)
}

We evaluated the association between serum level of CC-16 and asthma, lung function and airway responsiveness and showed that decreased serum CC-16 level is associated with decreased lung function and higher airway responsiveness in participants without asthma.

\begin{abstract}
Background and objective

Club cell secretory protein (CC-16) is a sensitive biomarker of airways epithelium integrity and because of its presumed relationship to inflammation, has gained increasing interest as biological marker in the study of chronic pulmonary diseases. Nevertheless little evidence exists of an association between CC-16 serum levels and asthma, lung function and airway responsiveness.
\end{abstract}

\section{Methods}

Serum CC-16 level was determined by latex immunoassay in 1298 participants from the French Epidemiological case-control and family-based study on Genetics and Environment of Asthma (EGEA) (mean age 43 years; 49\% men, 38\% with asthma). Pre-bronchodilator lung function (Forced Expiratory Volume in one second $\left(\mathrm{FEV}_{1}\right)$, Forced Vital Capacity (FVC) and $\mathrm{FEV}_{1} / \mathrm{FVC}$ ) and degree of airway responsiveness, expressed as a function of the doseresponse slope to methacholine test were measured. Standardized residuals (CC-16 z-score) obtained by regressing $\mathrm{CC}-16$ level on the glomerular filtration rate were studied in association with asthma, lung function and airway responsiveness in participants with and without asthma.

\section{Results}

CC-16 geometric mean level was $12.4 \mu \mathrm{g} / \mathrm{L}$ (range: 2.2 - $70.6 \mu \mathrm{g} / \mathrm{L}$ ). In participants without asthma, lower CC-16 z-score was associated with impaired $\mathrm{FEV}_{1} / \mathrm{FVC} \%$ (beta $=0.50(95 \% \mathrm{CI}$ : $0.06,0.95)$ and with higher degree of airway responsiveness (beta=0.24 (95\%CI: 0.09, 0.39)). 
CC-16 was not associated with impaired lung function or airway responsiveness in participant with asthma.

Conclusions

Lower CC-16 serum level was associated with impaired lung function and higher degree of airway responsiveness, suggesting that serum CC-16 level may reflect early damages of the lung epithelium integrity in adults without asthma.

\section{Keywords}

Uteroglobin; asthma; lung function test; airway hyper-reactivity; biological marker

\section{Short title}

CC-16 level and airway responsiveness 


\section{INTRODUCTION}

Club cell protein (CC-16, also called CC10, SCGB1A1 or CCSP) is mainly secreted by the club cells along the tracheobronchial tree, diffuses passively into the bloodstream, and is finally rapidly eliminated by glomerular filtration ${ }^{1}$.

While the exact function of CC-16 is not known, it is suggested to be a protective mediator in the airway inflammatory process ${ }^{2}$ and to have protective effects from oxidative stress on the respiratory tract ${ }^{3,4}$. Serum CC-16 level is considered as a sensitive biomarker of airways epithelium integrity, transiently increasing following acute exposure to pulmonary irritants and decreasing after chronic exposures associated with an impairment or reduction of club cells. Overall the assay of CC-16 is a sensitive test to allow the detection of early damage to the respiratory epithelium ${ }^{3}$ and because of its presumed relationship to inflammation, CC-16 has gained increasing interest as a biological marker in the study of chronic pulmonary diseases 5,6 .

Asthma is a chronic inflammatory disorder of the airways characterised by increased airway responsiveness (AR) and associated with accelerate decline in lung function ${ }^{7}$. Although $\mathrm{AR}$ is a key characteristic of asthma ${ }^{8}$ it may occur without asthma-like symptoms or previous diagnosis of asthma, which is called asymptomatic AR. ${ }^{9}$.

Findings on the association between CC-16 and asthma are conflicting. No association with asthma was observed in adults from a large cross-sectional study ${ }^{10}$, while a negative association was observed in participants with asthma in clinical studies ${ }^{11,12}$. Only few large epidemiological studies evaluated the association between CC-16 level and lung function, providing evidence of a negative association ${ }^{10,13-15}$. A negative association between serum CC-16 level and AR was described only in one cross-sectional study ${ }^{14}$, and no study evaluated the specific association with asymptomatic AR. Overall there is a lack of large epidemiological studies considering together the relations of serum CC-16 with asthma, lung function and AR. Our hypothesis is that serum level of CC-16 decreases in participants with 
asthma, impaired lung function and airway responsiveness. The aim of the present paper is to study the associations between serum CC-16 levels and asthma, impaired lung function and airway responsiveness in the French epidemiological study on the genetics and environment of asthma (EGEA) whom participants with or without asthma have been extensively characterized regarding respiratory phenotypes and lung function tests.

\section{METHODS}

\section{Study population}

EGEA is a cohort study based on an initial group of asthma cases, their first-degree relatives, and controls (first survey, $\mathrm{n}=2047)^{16}$. At the second survey ${ }^{17}$, detailed phenotyping was performed with lung function tests including methacholine challenge (see Figure 1 and the online supplemental population and protocol section). This analysis is based on participants who were adults at the second survey ( $\geq 16$ years old, $n=1570$ adults) with available data on asthma, serum CC-16 level and who did not smoke 1 hour before the examination $(\mathrm{N}=1298)$.

\section{Biological phenotypes}

Serum CC-16 level was determined with latex immunoassay using a rabbit anti-CC-16 antibody (Dakopatts, Glostrup, Denmark) ${ }^{18}$ and purified CC-16 protein as standards (see the online supplemental biological phenotypes section).

Serum creatinine was determined with standard traceable IDMS (isotope dilution mass spectrometry traceable) assay and its clearance was calculated by the CKD-EPI (Chronic Kidney Disease Epidemiology Collaboration) formula ${ }^{19}$ which depends on sex and age of participants.

\section{Clinical phenotypes}




\section{Asthma and asthma related phenotypes}

Current asthma referred to the report of asthma attacks or asthma treatment or asthma-like symptoms in the past 12 months ${ }^{20}$. Participants without current asthma and that never reported ever asthma were considered as controls. Based on five asthma symptoms over the past 12 months (wheezy breathlessness, woken up by chest tightness and by an attack of shortness of breath, attack of shortness of breath at rest and after exercise), the asthma symptom score was computed, as previously proposed ${ }^{21,22}$.

Asthma control was assessed from survey questions and lung function, closely adapted from the 2006-2009 Global Initiative for Asthma guidelines 2006, as previously described in ${ }^{20}$ (see online supplemental population and protocol section for more details).

\section{Pulmonary function}

Pulmonary function test was performed using a standardized protocol with similar equipment across centres according to the ATS/ERS guidelines. FEV 1 and FVC percent predicted values were based on Stanojevic et al. reference equations ${ }^{23}$.

\section{Airway responsiveness}

Methacholine bronchial challenge test was performed in participants with no medical contraindication, unless baseline $\mathrm{FEV}_{1}<80 \%$ predicted or $\mathrm{FEV}_{1}$ post dilution was lower than $90 \%$ of the baseline $\mathrm{FEV}_{1}$, following the same protocol the European Community Respiratory Health Survey (ECRHS) ${ }^{24}$. Airway hyper-responsiveness (AHR) was defined as a $20 \%$ fall in $\mathrm{FEV}_{1}$ from the highest $\mathrm{FEV}_{1}$ postdiluent $\left(\mathrm{PD}_{20}\right)$ during the test with an accumulated dose of methacholine. "High $\mathrm{AHR}$ " refers to a $\mathrm{PD}_{20}$ related to an accumulated methacholine dose of 1 $\mathrm{mg}\left(\mathrm{PD}_{20} \leq 1 \mathrm{mg}\right)$ and "any $\mathrm{AHR}$ " refers to a $\mathrm{PD}_{20} \leq 4 \mathrm{mg}$.

The degree of airway responsiveness was quantified by a transformed dose-response slope obtained regressing the percentage fall in $\mathrm{FEV}_{1}$ on $\log 10$ methacholine dose ${ }^{25}$. Low values of 
slope correspond to high degree of bronchial responsiveness. We referred to participants without asthma but with airway responsiveness as "asymptomatic AR".

\section{Ethics Statement}

Ethical approval was obtained from the relevant institutional review board committees at Cochin Port-Royal Hospital and Necker-Enfants Malades Hospital, Paris. Written informed consent was signed by kin or guardians of the minors/children and all other adult participants.

\section{Statistical analyses}

Since CC-16 level strongly depends on glomerular filtration rate (eGFR) level (Table 1), we obtained eGFR-adjusted residuals by regressing log-transformed CC-16 on eGFR and used the standardized residuals $(\mathrm{CC}-16 \mathrm{z}$-score, Mean $=0, \mathrm{SD}=1)$ in the subsequent analysis as independent variable. Association between $\mathrm{CC}-16$ and asthma was estimated with a logistic regression model. Since the expression of CC-16 is known to be inducible by corticosteroids

${ }^{26}$, association with asthma was repeated after excluding participants who used inhaled corticosteroids during the previous 12 months $(n=265)$. To account for the specific design of the EGEA study analyses on lung function and AR were conducted separately in participant with and without asthma and estimates were obtained with linear or logistic regression model, where appropriate. All parameters were estimated with generalized estimating equations (GEE) with an exchangeable working correlation to account for the potential clustering within the families. Estimates were adjusted for sex, smoking status and pack-years, age and height when needed. Since CC-16 has shown a time-dependent daily variation, ${ }^{27}$ blood sampling time (range $7-20 \mathrm{~h}$ ) was included as covariate. Further, to test whether the association between $\mathrm{CC}-16$ and AR was independent from the bronchial calibre of participants, the level of $\mathrm{FEV}_{1} \%$ predicted was added as a covariate in the multivariate model. Finally, since tobacco smoke is associated with decreased level of CC-16, as well as with impaired lung function 
and increased AR, the analyses were stratified by smoking status. All statistical analyses were performed using $\mathrm{R}$ version $2.14 .^{28}$

\section{RESULTS}

Characteristics of the sample (Table 1)

The study population included 1298 participants with a mean age of 43 years (range 16-80 years). Lung function test was performed by 1278 participants: among them 416 did not perform the methacholine test because of poor lung function $(n=113)$ or other reasons $(n=303)$ and data on AR were available for 862 participants (see online result section for more details).

\section{CC-16 Serum level}

Overall, serum CC-16 geometric mean (GM) level was $12.4 \mu \mathrm{g} / \mathrm{L}$, ranging from 2.2 to 70.6 $\mu \mathrm{g} / \mathrm{L}$ (Table 1). CC-16 level was higher in men, increased with age, decreased in smokers and with pack-years smoked decreased with blood sampling time and was negatively correlated with eGFR (Table 2). After adjustment for eGFR and blood sampling time, the negative associations with age and smoking were confirmed only in participants without asthma (beta $=-0.04, p=0.06$ and beta for trend $=-0.08, p=0.006$, respectively).

\section{Associations between CC-16 and asthma}

Univariate association between CC-16 level and current asthma (as reported in Table 1) was no longer confirmed after adjustment for eGFR (beta $=0.88(95 \%$ CI $0.74,1.05))$ and when eGFR adjusted CC-16 z-score was considered as predictive variable $\left(\mathrm{OR}_{\mathrm{adj}}=0.92(95 \% \mathrm{CI}\right.$ : $0.82,1.02))$. No association was observed between CC-16 z-score and asthma in participants not treated by inhaled corticosteroids $\left(n=265, \mathrm{OR}_{\mathrm{adj}}=0.94(95 \% \mathrm{CI} 0.82,1.09)\right)$, nor by oral corticosteroids or anti-leukotriene (alone or combined, data not shown).

In participants with asthma, no association was observed between CC-16 z-score and asthma 
control ( $p>0.10)$ or asthma score $(p=0.08$ for score $\geq 2)$ and CC-16 levels did not vary with ICS use $(\mathrm{GM}=11.7(95 \% \mathrm{CI} 8.03,15.4) \mu \mathrm{g} / \mathrm{L}$ and $\mathrm{GM}=11.9(95 \% \mathrm{CI} 8.35,15.5) \mu \mathrm{g} / \mathrm{L}, \mathrm{p}=0.16$, in participants no-ICS and ICS users respectively).

\section{Associations between CC-16 and lung function}

In participants with asthma, no association was observed between $\mathrm{CC}-16$ and lung function (table E1, online), and this result was confirmed also in non-ICS users $(n=253, p=0.10)$.

In participants without asthma (Table 3), reduced $\mathrm{FEV}_{1} \%$ predicted (borderline significant) and $\mathrm{FEV}_{1} / \mathrm{FVC}$ were associated with reduced CC-16 z-score, considered both on a continuous scale and categorized into quartiles (Figure E1, online). Association with lung function was higher in current smokers than in never smokers (Figure 2E, online), with statistically significant interactions for $\mathrm{FEV}_{1} \%$ predicted and $\mathrm{FEV}_{1} / \mathrm{FVC}$.

\section{Associations between CC-16 and AR}

CC-16 GM level decreased from 12.2 (95\%CI: 11.7, 12.7) $\mu \mathrm{g} / \mathrm{L}$ in participants who performed the methacholine challenge test $(\mathrm{N}=862)$ to $11.1(95 \% \mathrm{CI} 9.75,12.5) \mu \mathrm{g} / \mathrm{L}$ in 113 participants who did not performed the test because of poor lung function.

In participants with asthma no association was observed between $\mathrm{CC}-16 \mathrm{z}$-score and AR (table E1 online), and this result was confirmed also in non-ICS users.

In participants without asthma lower CC-16 level was associated with lower level in the doseresponse slope (Figure 2a) borderline higher risk of any AHR (PD20 $\leq 4 \mathrm{mg})$ and high AHR $\left(\mathrm{PD}_{20} \leq 1 \mathrm{mg}\right)$ (Table 3$)$. These results were confirmed also when $\mathrm{FEV}_{1} \%$ predicted was included in the multivariate model (beta for the slope: 0.20 (95\%CI: $0.05,0.35)$ ) and when only participants without any asthma symptom (asthma score $<2)$ were considered $(n=465$, beta for the slope $=0.23(95 \% \mathrm{CI} 0.07,0.39))$. Similar results were observed when CC-16 zscore was grouped in quartiles (Figure E1, online). Participants in the highest CC-16 z-score 
quartile were associated with lower slope $\left(\right.$ beta $\left._{a d j}=0.50(95 \% \mathrm{CI}: 0.08,0.92)\right)$ and a lower risk of high AHR $\left(\mathrm{OR}_{\mathrm{adj}}=0.30(95 \% \mathrm{CI}: 0.12,0.75)\right)$ than participants in the lowest CC-16 z-score quartile.

Interaction between smoking and CC-16 z-score was statistically significant for the slope $(\mathrm{p}=0.02)$ (Figure $2 \mathrm{E}$ online). After adjustment for covariates, lower CC-16 $\mathrm{z}$-score was associated with lower slope both in current as well as in ex-smokers (beta $a_{\text {adj }}=0.50(95 \% \mathrm{CI}$ : $0.21,0.79)$, beta $_{\mathrm{adj}}=0.24(95 \% \mathrm{CI}: 0.01,0.46)$, respectively $)$.

\section{DISCUSSION}

Using data from a large epidemiological study on asthma, we observed that reduced lung function and higher AR were associated with decreased CC-16 level only in participants without asthma. No significant association was observed between CC-16 level and current asthma.

The major assets of this study are the sample size, the standardization of the sample collection and the availability of clinical parameters. Definition of asthma case is precise ${ }^{29}$ leading to a very limited risk of false positives. Serum CC-16 level were similar to the reference values in healthy non-smokers (between 10 and $15 \mu \mathrm{g} / \mathrm{L}$ on average) ${ }^{3}$. Prevalence of airway hyperresponsiveness, measured by a methacholine challenge test was quite high in participants without asthma. A possible explanation is that part of the participants without asthma is first degree relatives of asthma cases. Nevertheless, this result is consistent with the relatively considerable number of asymptomatic participants with AHR reported in cross-sectional epidemiologic studies, ranging from 19.3 to $62.4 \%{ }^{30}$

CC-16 level was standardized on eGFR so that all the associations were not affected by eGFR's sex and age-related variation. CC-16 decreased with smoking and pack-years smoked, varied with blood sampling time and was negatively associated with eGFR, consistent with previously published results ${ }^{31}$. However, with a cross-sectional approach, 
causal association between CC-16 and respiratory diseases could not be established.

We found no association between CC-16 level and asthma. Similarly, no association was observed with asthma in 859 participants to population-based multi-centre ECRHS ${ }^{10}$ neither with asthma and bronchitis in 6531 men aged $67-77$ year from a cross-sectional study ${ }^{32}$. To date, most evidence of an association between CC-16 and asthma comes from small (less than 100 participants) clinical studies, both in children ${ }^{33,34}$ and in adults ${ }^{11,12}$. A possible explanation for this apparent discrepancy is that participants from clinical studies are more likely to have severe asthma than participants from population-based studies. Further, clinical samples are known to be vulnerable to selection bias that may compromise the generalizability of findings.

We found that $\mathrm{FEV}_{1}$ and $\mathrm{FEV}_{1} / \mathrm{FVC}$ were associated with serum $\mathrm{CC}-16$ level only in participants without asthma. Previously, a positive association between serum CC-16 and $\mathrm{FEV}_{1}$ and FVC was observed by in 402 fire-fighters from a cross-sectional study ${ }^{14}$ and with $\mathrm{FEV}_{1} \%$ predicted and $\mathrm{FEV}_{1} / \mathrm{FVC}$ ratio in adults from the general population in the ECHRS study ${ }^{10}$, after adjustment for the same large range of covariates, including blood sampling time. The association between lung function parameters and CC-16 found in our study is consistent with previous published results on an association between lung function and markers of inflammation, such as C-Reactive Protein ${ }^{35}$.

We observed a negative association between CC-16 level and AR in adults without asthma that was confirmed in participants without any asthmatic symptom and was also independent from bronchial calibre. To the best of our knowledge this is the first study showing an association between CC-16 and asymptomatic AR. Previously, a negative association between AR and CC-16, apparently unnoticed by the authors, was observed in 4724 smokers with mild to moderate airflow limitation from the Lung Health Study ${ }^{13}$ and in 402 fire-fighters, after adjustment for smoking and atopic status ${ }^{14}$. These findings may be related to mild inflammatory changes, that are present in airway mucosa of patients with AHR ${ }^{36}$ that may 
lead to damages of airway epithelium and consequent decreased number of club cells in small airways ${ }^{37}$. Alternatively, genetically determined lower level of CC-16 and subsequent fragile epithelium may contribute to the development of asymptomatic AHR. In such case, methacholine or any other bronchoconstrictive substance may easily penetrate the lung epithelium and induce bronchial hyperreactivity. This hypothesis is supported by the findings of Taniguchi and colleagues ${ }^{38}$, that showed that the A38G polymorphism in the CC-16 gene was associated with both plasma CC-16 level and AR in 154 asymptomatic, young, healthy adults. In the EGEA study, we previously found that methacholine AHR was significantly related to asthma incidence in asymptomatic participants ${ }^{9}$. It could be postulated that asymptomatic AR might precede development of respiratory symptoms and asthma ${ }^{36,37}$ through mechanisms related with airway inflammation, damage to epithelium integrity and structural changes in the airway mucosa ${ }^{39}$ that are associated with decreased CC-16 levels in the airway. Future longitudinal studies, especially on paediatric population, will be useful to evaluate the role of CC-16 as a prognostic marker for asthma.

The lack of association between CC-16 level and lung function or AR in asthmatic group could be partly explained by the complex mechanisms, including inflammation and oxidative stress that characterizes this disease, leading to less variability of CC-16 level in participants with asthma and less sensitivity to variation in AR. Further, the differential association between $\mathrm{CC}-16$ and lung function and $\mathrm{AR}$ between participants without and with asthma support the evidence of heterogeneity of AR in asymptomatic and symptomatic participants 30 .

In conclusion, we observed that decreased CC-16 serum level were associated with asymptomatic airway responsiveness and impaired lung function, only in participants without asthma. Those results suggested that serum level of CC-16 may help detecting early damages of the lung epithelium integrity. Further longitudinal studies will help in understanding whether this information will be used for early detecting asthmatic trait. 
Funding: Research funded by the European Respiratory Society (Fellowship LTRF fellowship $\mathrm{n}^{\circ}$ 123-2011) and the NETA project (French Agency of Health Safety, Environment and Work (AFSSET, EST-09-15).

\section{Acknowledgments}

The authors thank all those who participated in the study and in the various aspects of the examinations and all those who supervised the study in all centers. The authors are grateful to the three CIC-Inserm units of Necker, Grenoble and Marseille which supported the study and where subjects were examined. They are also grateful to the three biobanks in Lille (CICInserm), Evry (Centre National de Genotypage) and Annemasse (Etablissement francais du sang) where biological samples are stored. They are indebted to all the individuals who participated, without whom the study would not have been possible.

\section{EGEA cooperative group}

Coordination: V Siroux (epidemiology, PI since 2013); F Demenais (genetics); I Pin (clinical aspects); R Nadif (biology); F Kauffmann (PI 1992-2012).

Respiratory epidemiology: Inserm U 700, Paris: M Korobaeff (Egea1), F Neukirch (Egea1); Inserm U 707, Paris: I Annesi-Maesano (Egea1-2); Inserm CESP/U 1018, Villejuif: F Kauffmann, N Le Moual, R Nadif, MP Oryszczyn (Egea1-2), R Varraso; Inserm U 823, Grenoble: V Siroux.

Genetics: Inserm U 393, Paris: J Feingold; Inserm U 946, Paris: E Bouzigon, F Demenais, MH Dizier; CNG, Evry: I Gut (now CNAG, Barcelona, Spain), M Lathrop (now Univ McGill, Montreal, Canada).

Clinical centers: Grenoble: I Pin, C Pison; Lyon: D Ecochard (Egea1), F Gormand, Y Pacheco; Marseille: D Charpin (Egea1), D Vervloet (Egea1-2); Montpellier: J Bousquet; Paris Cochin: A Lockhart (Egea1), R Matran (now in Lille); Paris Necker: E Paty (Egea1-2), P Scheinmann (Egea1-2); Paris-Trousseau: A Grimfeld (Egea1-2), J Just. 
Data and quality management: Inserm ex-U155 (Egea1): J Hochez; Inserm CESP/U 1018, Villejuif: N Le Moual; Inserm ex-U780: C Ravault (Egea1-2); Inserm ex-U794: N Chateigner (Egea1-2); Grenoble: J Quentin-Ferran (Egea1-2).

\section{REFERENCES}

1. Broeckaert F, Clippe A, Knoops B, Hermans C, Bernard A. Clara cell secretory protein (CC16): features as a peripheral lung biomarker. Ann N Y Acad Sci 2000;923:68-77.

2. Jorens PG, Sibille Y, Goulding NJ, van Overveld FJ, Herman AG, Bossaert L, De Backer WA, Lauwerys R, Flower RJ, Bernard A. Potential role of Clara cell protein, an endogenous phospholipase A2 inhibitor, in acute lung injury. Eur Respir J Off J Eur Soc Clin Respir Physiol 1995;8:1647-53.

3. Broeckaert F, Bernard a. Clara cell secretory protein $(\mathrm{CC} 16)$ : characteristics and perspectives as lung peripheral biomarker. Clin Exp Allergy 2000;30:469-75.

4. Mango GW, Johnston CJ, Reynolds SD, Finkelstein JN, Plopper CG, Stripp BR. Clara cell secretory protein deficiency increases oxidant stress response in conducting airways. Am J Physiol 1998;275:L348-L356.

5. Faner R, Tal-Singer R, Riley JH, Celli B, Vestbo J, Macnee W, Bakke P, Calverley PMA, Coxson H, Crim C, Edwards LD, Locantore N, Lomas DA, Miller BE, Rennard SI, Wouters EFM, Yates JC, Silverman EK, Agusti A. Lessons from ECLIPSE: a review of COPD biomarkers. Thorax 2013;doi:10.1136/thoraxjnl-2013-204778.

6. Celli BR, Owen $\mathrm{C}$ a. The club cell and its protein, $\mathrm{CC} 16$ : time to shine. lancet Respir Med 2013;1:757-9.

7. Lange P, Parner J, Vestbo J, Schnohr P, Jensen G. The course of pulmonary function in adults with asthma. The Osterbro study. Ugeskr Laeger 2000;162:487-490.

8. National Asthma Education and Prevention Program. Expert Panel Report 3 (EPR-3): 
Guidelines for the Diagnosis and Management of Asthma-Summary Report 2007. J Allergy Clin Immunol 2007.

9. Rage E, Siroux V, Le Moual N, Pin I, Kauffmann F. Re: Are asymptomatic airway hyperresponsiveness and allergy risk factors for asthma? A longitudinal study. Eur Respir J 2009;33:218-9.

9. Rava M, Tares L, Lavi I, Barreiro E, Zock J-P, Ferrer A, Muniozguren N, Nadif R, Cazzoletti L, Kauffmann F, Anto JM, Guerra S. Serum levels of Clara cell secretory protein, asthma, and lung function in the adult general population. J Allergy Clin Immunol $2013 ; 132: 230-2$.

10. Ye Q, Fujita M, Ouchi H, Inoshima I, Maeyama T, Kuwano K, Horiuchi Y, Hara N, Nakanishi Y. Serum CC-10 in inflammatory lung diseases. Respiration 2004;71:505-10.

11. Shijubo N, Itoh Y, Yamaguchi T, Sugaya F, Hirasawa M, Yamada T, Kawai T, Abe S. Serum levels of Clara cell $10-\mathrm{kDa}$ protein are decreased in patients with asthma. Lung $1999 ; 177: 45-52$.

12. Park HY, Churg A, Wright JL, Li Y, Tam S, Man SP, Tashkin D, Wise RA, Connett JE, Sin DD. Club Cell Protein 16 and Disease Progression in Chronic Obstructive Pulmonary Disease (COPD). Am J Respir Crit Care Med 2013;doi:10.1164/rccm.201305-0892OC.

13. Greven F, Krop E, Burger N, Kerstjens H, Heederik D. Serum pneumoproteins in firefighters. Biomarkers 2011;16:364-71.

14. Vestbo J, Edwards LD, Scanlon PD, Yates JC, Agusti A, Bakke P, Calverley PM a, Celli B, Coxson HO, Crim C, Lomas D a, MacNee W, Miller BE, Silverman EK, Tal-Singer R, Wouters E, Rennard SI. Changes in forced expiratory volume in 1 second over time in COPD. N Engl J Med 2011;365:1184-92.

15. Kauffmann F, Dizier MH. EGEA (Epidemiological study on the Genetics and Environment of Asthma, bronchial hyperresponsiveness and atopy)--design issues. EGEA Co-operative Group. Clin Exp Allergy 1995;25 Suppl 2:19-22. 
16. Rava M, Varraso R, Decoster B, Huyvaert H, Le Moual N, Jacquemin B, Künzli N, Kauffmann F, Zerimech F, Matran R, Nadif R. Plasma and exhaled breath condensate nitritenitrate level in relation to environmental exposures in adults in the EGEA study. Nitric Oxide 2012;27:169-75.

17. Hermans C, Aly O, Nyberg B, Peterson C, Bernard A. Determinants of Clara cell protein ( $\mathrm{CC} 16$ ) concentration in serum : a reassessment with two different immunoassays. Clin Chim acta 1998;272:101-110.

18. Stevens LA, Schmid CH, Greene T, Zhang YL, Beck GJ, Froissart M, Hamm LL, Lewis JB, Mauer M, Navis GJ, Steffes MW, Eggers PW, Coresh J, Levey AS. Comparative performance of the CKD Epidemiology Collaboration (CKD-EPI) and the Modification of Diet in Renal Disease (MDRD) Study equations for estimating GFR levels above 60 $\mathrm{mL} / \mathrm{min} / 1.73 \mathrm{~m} 2$. Am J Kidney Dis 2010;56:486-95.

19. Siroux V, Boudier A, Bousquet J, Bresson J-L, Cracowski J-L, Ferran J, Gormand F, Just J, Le Moual N, Morange S, Nadif R, Oryszczyn M-P, Pison C, Scheinmann P, Varraso R, Vervloet D, Pin I, Kauffmann F. Phenotypic determinants of uncontrolled asthma. J Allergy Clin Immunol 2009;124:681-7.e3.

20. Sunyer J, Pekkanen J, Garcia-Esteban R, Svanes C, Künzli N, Janson C, De Marco R, Antó JM, Burney P. Asthma score: Predictive ability and risk factors. Allergy Eur J Allergy Clin Immunol 2007;62:142-148.

21. Pekkanen J, Sunyer J, Anto JM, Burney P. Operational definitions of asthma in studies on its aetiology. Eur Respir J Off J Eur Soc Clin Respir Physiol 2005;26:28-35.

22. Stanojevic S, Wade A, Stocks J, Hankinson J, Coates A, Pan H, Rosenthal M, Corey M, Lebecque P, Cole T. Reference ranges for spirometry across all ages - A new approach. Am J Respir Crit Care Med 2008;177:253-260.

23. Chinn S, Burney P, Jarvis D, Luczynska C. Variation in bronchial responsiveness in the European Community Respiratory Health Survey (ECRHS). Eur Respir J 1997;10:2495- 
2501.

24. Chinn S, Arossa W a., Jarvis DL, Luczynska CM, Burney PGJ. Variation in nebulizer aerosol output and weight output from the Mefar dosimeter: implications for multicentre studies. Eur Respir J 1997;10:452-456.

24. Mukherjee AB, Zhang Z, Chilton BS. Uteroglobin: a steroid-inducible immunomodulatory protein that founded the Secretoglobin superfamily. Endocr Rev 2007;28:707-25.

25. Helleday R, Segerstedt B, Forsberg B, Mudway I, Nordberg G, Bernard A, Blomberg A. Exploring the time dependence of serum clara cell protein as a biomarker of pulmonary injury in humans. Chest 2006;130:672-5.

26. R Development Core Team R. R: A Language and Environment for Statistical Computing. R Found Stat Comput 2011;

27. Kauffmann F, Dizier MH, Pin I, Paty E, Gormand F, Vervloet D, Bousquet J, Neukirch F, Annesi I, Oryszczyn MP, Lathrop M, Demenais F, Lockhart A, Feingold J. Epidemiological study of the genetics and environment of asthma, bronchial hyperresponsiveness, and atopy: phenotype issues. Am J Respir Crit Care Med 1997;156:S123-9.

28. Jansen D, Timens W, Kraan J. (A) symptomatic bronchial hyper-responsiveness and asthma. Respir Med 1997;2:121-134.

29. Lakind JS, Holgate ST, Ownby DR, Mansur a H, Helms PJ, Pyatt D, Hays SM. A critical review of the use of Clara cell secretory protein $(\mathrm{CC} 16)$ as a biomarker of acute or chronic pulmonary effects. Biomarkers 2007;12:445-67.

30. Madsen C, Durand KL, Nafstad P, Schwarze PE, Rønningen KS, Håheim LL. Associations between environmental exposures and serum concentrations of Clara cell protein among elderly men in Oslo, Norway. Environ Res 2008;108:354-60.

31. Gioldassi XM, Papadimitriou H, Mikraki V, Karamanos NK. Clara cell secretory 
protein: determination of serum levels by an enzyme immunoassay and its importance as an indicator of bronchial asthma in children. J Pharm Biomed Anal 2004;34:823-6.

32. Laing IA, Hermans C, Bernard A, Burton PR, Goldblatt J, Le Souëf PN. Association between plasma CC16 levels, the A38G polymorphism, and asthma. Am J Respir Crit Care Med 2000;161:124-7.

33. Ye Q, Fujita M, Ouchi H, Inoshima I, Maeyama T, Kuwano K, Horiuchi Y, Hara N, Nakanishi Y. Serum CC-10 in inflammatory lung diseases. Respiration 2004;71:505-10.

35. Laprise C, Laviolette $\mathrm{M}$, Boutet $\mathrm{M}$, Boulet LP. Asymptomatic airway hyperresponsiveness: Relationships with airway inflammation and remodelling. Eur Respir J 1999;14:63-73.

35. Kony S, Zureik M, Driss F, Neukirch C, Leynaert B, Neukirch F. Association of bronchial hyperresponsiveness and lung function with $\mathrm{C}$-reactive protein (CRP): a population based study. Thorax 2004;59:892-6.

36. Holgate ST. The sentinel role of the airway epithelium in asthma pathogenesis. Immunol Rev 2011;242:205-19.

37. Taniguchi N, Konno S, Hattori T, Isada A, Shimizu K, Shimizu K, Shijubo N, Huang S-K, Hizawa N, Nishimura M. The CC16 A38G polymorphism is associated with asymptomatic airway hyper-responsiveness and development of late-onset asthma. Ann Allergy Asthma Immunol 2013;111:376-381.e1.

38. Rage E, Siroux V, Le Moual N, Pin I, Kauffmann F. Re: Are asymptomatic airway hyperresponsiveness and allergy risk factors for asthma? A longitudinal study. Eur Respir J 2009;33:218-9.

39. Laprise C, Boulet LP. Asymptomatic airway hyperresponsiveness: a three-year follow-up. Am J Respir Crit Care Med 1997;156:403-9.

40. Quanjer PH, Tammeling GJ, Cotes JE, Pedersen OF, Peslin R, Yernault JC. Lung volumes and forced ventilatory flows. Report Working Party Standardization of Lung 
Function Tests, European Community for Steel and Coal. Official Statement of the European Respiratory Society. Eur Respir J Suppl 1993;16:5-40. 
REFERENCES (final version)

1. Broeckaert F, Clippe A, Knoops B, Hermans C, Bernard A. Clara cell secretory protein (CC16): features as a peripheral lung biomarker. Ann N Y Acad Sci 2000;923:68-77.

2. Jorens PG, Sibille Y, Goulding NJ, van Overveld FJ, Herman AG, Bossaert L, De Backer WA, Lauwerys R, Flower RJ, Bernard A. Potential role of Clara cell protein, an endogenous phospholipase A2 inhibitor, in acute lung injury. Eur Respir $J$ Off J Eur Soc Clin Respir Physiol 1995;8:1647-53.

3. Broeckaert F, Bernard a. Clara cell secretory protein (CC16): characteristics and perspectives as lung peripheral biomarker. Clin Exp Allergy 2000;30:469-75.

4. Mango GW, Johnston CJ, Reynolds SD, Finkelstein JN, Plopper CG, Stripp BR. Clara cell secretory protein deficiency increases oxidant stress response in conducting airways. Am J Physiol 1998;275:L348-L356.

5. Faner R, Tal-Singer R, Riley JH, Celli B, Vestbo J, Macnee W, Bakke P, Calverley PMA, Coxson H, Crim C, Edwards LD, Locantore N, Lomas DA, Miller BE, Rennard SI, Wouters EFM, Yates JC, Silverman EK, Agusti A. Lessons from ECLIPSE: a review of COPD biomarkers. Thorax 2013;doi:10.1136/thoraxjnl-2013-204778.

6. Celli BR, Owen $\mathrm{C}$ a. The club cell and its protein, CC16: time to shine. Lancet Respir Med 2013;1:757-9.

7. Lange P, Parner J, Vestbo J, Schnohr P, Jensen G. The course of pulmonary function in adults with asthma. The Osterbro study. Ugeskr Laeger 2000;162:487-490.

8. National Asthma Education and Prevention Program. Expert Panel Report 3 (EPR-3): Guidelines for the Diagnosis and Management of Asthma-Summary Report 2007. J 
Allergy Clin Immunol 2007.

9. Rage E, Siroux V, Le Moual N, Pin I, Kauffmann F. Re: Are asymptomatic airway hyperresponsiveness and allergy risk factors for asthma? A longitudinal study. Eur Respir J 2009;33:218-9.

10. Rava M, Tares L, Lavi I, Barreiro E, Zock J-P, Ferrer A, Muniozguren N, Nadif R, Cazzoletti L, Kauffmann F, Anto JM, Guerra S. Serum levels of Clara cell secretory protein, asthma, and lung function in the adult general population. J Allergy Clin Immunol 2013;132:230-2.

11. Ye Q, Fujita M, Ouchi H, Inoshima I, Maeyama T, Kuwano K, Horiuchi Y, Hara N, Nakanishi Y. Serum CC-10 in inflammatory lung diseases. Respiration 2004;71:50510.

12. Shijubo N, Itoh Y, Yamaguchi T, Sugaya F, Hirasawa M, Yamada T, Kawai T, Abe S. Serum levels of Clara cell 10-kDa protein are decreased in patients with asthma. Lung $1999 ; 177: 45-52$.

13. Park HY, Churg A, Wright JL, Li Y, Tam S, Man SP, Tashkin D, Wise RA, Connett JE, Sin DD. Club Cell Protein 16 and Disease Progression in Chronic Obstructive Pulmonary Disease (COPD). Am J Respir Crit Care Med 2013;doi:10.1164/rccm.201305-0892OC.

14. Greven F, Krop E, Burger N, Kerstjens H, Heederik D. Serum pneumoproteins in firefighters. Biomarkers 2011;16:364-371.

15. Vestbo J, Edwards LD, Scanlon PD, Yates JC, Agusti A, Bakke P, Calverley PM a, Celli B, Coxson HO, Crim C, Lomas D a, MacNee W, Miller BE, Silverman EK, Tal- 
Singer R, Wouters E, Rennard SI. Changes in forced expiratory volume in 1 second over time in COPD. N Engl J Med 2011;365:1184-92.

16. Kauffmann F, Dizier MH. EGEA (Epidemiological study on the Genetics and Environment of Asthma, bronchial hyperresponsiveness and atopy)--design issues. EGEA Co-operative Group. Clin Exp Allergy 1995;25 Suppl 2:19-22.

17. Rava M, Varraso R, Decoster B, Huyvaert H, Le Moual N, Jacquemin B, Künzli N, Kauffmann F, Zerimech F, Matran R, Nadif R. Plasma and exhaled breath condensate nitrite-nitrate level in relation to environmental exposures in adults in the EGEA study. Nitric Oxide 2012;27:169-75.

18. Hermans C, Aly O, Nyberg B, Peterson C, Bernard A. Determinants of Clara cell protein ( $\mathrm{CC} 16$ ) concentration in serum: a reassessment with two different immunoassays. Clin Chim acta 1998;272:101-110.

19. Stevens LA, Schmid CH, Greene T, Zhang YL, Beck GJ, Froissart M, Hamm LL, Lewis JB, Mauer M, Navis GJ, Steffes MW, Eggers PW, Coresh J, Levey AS. Comparative performance of the CKD Epidemiology Collaboration (CKD-EPI) and the Modification of Diet in Renal Disease (MDRD) Study equations for estimating GFR levels above $60 \mathrm{~mL} / \mathrm{min} / 1.73 \mathrm{~m} 2$. Am J Kidney Dis 2010;56:486-95.

20. Siroux V, Boudier A, Bousquet J, Bresson J-L, Cracowski J-L, Ferran J, Gormand F, Just J, Le Moual N, Morange S, Nadif R, Oryszczyn M-P, Pison C, Scheinmann P, Varraso R, Vervloet D, Pin I, Kauffmann F. Phenotypic determinants of uncontrolled asthma. J Allergy Clin Immunol 2009;124:681-7.e3.

21. Sunyer J, Pekkanen J, Garcia-Esteban R, Svanes C, Künzli N, Janson C, de Marco R, Antó JM, Burney P. Asthma score: predictive ability and risk factors. Allergy 
$2007 ; 62: 142-8$.

22. Pekkanen J, Sunyer J, Anto JM, Burney P. Operational definitions of asthma in studies on its aetiology. Eur Respir J Off J Eur Soc Clin Respir Physiol 2005;26:28-35.

23. Stanojevic S, Wade A, Stocks J, Hankinson J, Coates A, Pan H, Rosenthal M, Corey M, Lebecque P, Cole T. Reference ranges for spirometry across all ages - A new approach. Am J Respir Crit Care Med 2008;177:253-260.

24. Chinn S, Burney P, Jarvis D, Luczynska C. Variation in bronchial responsiveness in the European Community Respiratory Health Survey (ECRHS). Eur Respir $J$ 1997;10:2495-2501.

25. Chinn S, Arossa W a., Jarvis DL, Luczynska CM, Burney PGJ. Variation in nebulizer aerosol output and weight output from the Mefar dosimeter: implications for multicentre studies. Eur Respir J 1997;10:452-456.

26. Mukherjee AB, Zhang Z, Chilton BS. Uteroglobin: a steroid-inducible immunomodulatory protein that founded the Secretoglobin superfamily. Endocr Rev 2007;28:707-25.

27. Helleday R, Segerstedt B, Forsberg B, Mudway I, Nordberg G, Bernard A, Blomberg A. Exploring the time dependence of serum clara cell protein as a biomarker of pulmonary injury in humans. Chest 2006;130:672-5.

28. R Development Core Team R. R: A Language and Environment for Statistical Computing. R Found Stat Comput 2011;

29. Kauffmann F, Dizier MH, Pin I, Paty E, Gormand F, Vervloet D, Bousquet J, Neukirch F, Annesi I, Oryszczyn MP, Lathrop M, Demenais F, Lockhart A, Feingold J. 
Epidemiological study of the genetics and environment of asthma, bronchial hyperresponsiveness, and atopy: phenotype issues. Am J Respir Crit Care Med 1997;156:S123-9.

30. Jansen D, Timens W, Kraan J. (A) symptomatic bronchial hyper-responsiveness and asthma. Respir Med 1997;2:121-134.

31. Lakind JS, Holgate ST, Ownby DR, Mansur a H, Helms PJ, Pyatt D, Hays SM. A critical review of the use of Clara cell secretory protein $(\mathrm{CC} 16)$ as a biomarker of acute or chronic pulmonary effects. Biomarkers 2007;12:445-67.

32. Madsen C, Durand KL, Nafstad P, Schwarze PE, Rønningen KS, Håheim LL. Associations between environmental exposures and serum concentrations of Clara cell protein among elderly men in Oslo, Norway. Environ Res 2008;108:354-60.

33. Gioldassi XM, Papadimitriou H, Mikraki V, Karamanos NK. Clara cell secretory protein: determination of serum levels by an enzyme immunoassay and its importance as an indicator of bronchial asthma in children. $J$ Pharm Biomed Anal 2004;34:823-6.

34. Laing IA, Hermans C, Bernard A, Burton PR, Goldblatt J, Le Souëf PN. Association between plasma CC16 levels, the A38G polymorphism, and asthma. Am J Respir Crit Care Med 2000;161:124-7.

35. Kony S, Zureik M, Driss F, Neukirch C, Leynaert B, Neukirch F. Association of bronchial hyperresponsiveness and lung function with C-reactive protein (CRP): a population based study. Thorax 2004;59:892-6.

36. Laprise C, Laviolette M, Boutet M, Boulet LP. Asymptomatic airway hyperresponsiveness: Relationships with airway inflammation and remodelling. Eur 
Respir J 1999;14:63-73.

37. Holgate ST. The sentinel role of the airway epithelium in asthma pathogenesis. Immunol Rev 2011;242:205-19.

38. Taniguchi N, Konno S, Hattori T, Isada A, Shimizu K, Shimizu K, Shijubo N, Huang S-K, Hizawa N, Nishimura M. The CC16 A38G polymorphism is associated with asymptomatic airway hyper-responsiveness and development of late-onset asthma. Ann Allergy Asthma Immunol 2013;111:376-381.e1.

39. Laprise C, Boulet LP. Asymptomatic airway hyperresponsiveness: a three-year followup. Am J Respir Crit Care Med 1997;156:403-9.

40. Quanjer PH, Tammeling GJ, Cotes JE, Pedersen OF, Peslin R, Yernault JC. Lung volumes and forced ventilatory flows. Report Working Party Standardization of Lung Function Tests, European Community for Steel and Coal. Official Statement of the European Respiratory Society. Eur Respir J Suppl 1993;16:5-40. 
Table 1: Socio-demographic and clinical characteristics of the participants

\begin{tabular}{|c|c|c|c|c|}
\hline Characteristics & All & $\begin{array}{l}\text { Without } \\
\text { asthma }\end{array}$ & With asthma & $\mathbf{p}$ \\
\hline $\mathbf{N}$ & 1298 & 803 & 495 & \\
\hline Females, \% & 51.4 & 53.4 & 48.1 & 0.07 \\
\hline Age, mean (SD), years & $43.8(16.4)$ & $46.4(15.8)$ & $39.6(16.5)$ & $<0.001$ \\
\hline \multicolumn{5}{|l|}{ Smoking status } \\
\hline \multicolumn{5}{|l|}{ and intensity, \% } \\
\hline Lifetime non-smoker & 50.1 & 50.9 & 48.7 & $<0.001$ \\
\hline Ex-smoker, $<15$ pack-years & 19.2 & 20.2 & 17.5 & \\
\hline Ex-smoker, $\geq 15$ pack-years & 8.31 & 8.53 & 7.94 & \\
\hline Smoker, $<15$ pack-years & 16.5 & 12.9 & 22.4 & \\
\hline Smoker, $\geq 15$ pack-years & 5.9 & 7.4 & 3.46 & \\
\hline \multicolumn{5}{|l|}{ Asthma symptom score } \\
\hline 0 & 13.1 & 7.33 & 22.4 & $<0.001$ \\
\hline 1 & 86.9 & 92.7 & 77.6 & \\
\hline$\geq 2$ & 32.9 & 63.3 & 9.78 & \\
\hline Lung function test, $\mathbf{N}$ & 1278 & 791 & 487 & \\
\hline $\mathrm{FEV}_{1} \%$ predicted ${ }^{*}$, Mean $(\mathrm{SD})$ & $97.0(17.1)$ & $100.8(15.2)$ & $90.8(18.2)$ & $<0.001$ \\
\hline FVC $\%$ predicted*, Mean (SD) & $99.7(14.7)$ & $100.8(14.5)$ & $98.0(14.8)$ & 0.001 \\
\hline $\mathrm{FEV}_{1} / \mathrm{FVC}$, Mean (SD) & $77.9(9.32)$ & $79.8(7.37)$ & $74.9(11.2)$ & $<0.001$ \\
\hline $\mathrm{FEV}_{1} \%$ predicted $*>80 \%, \%$ & 86.9 & 92.7 & 77.6 & $<0.001$ \\
\hline Methacholine & 862 & 540 & 322 & \\
\hline \multicolumn{5}{|l|}{ challenge test, $N$} \\
\hline \multicolumn{5}{|l|}{ Dose-response slope, } \\
\hline N, Mean (SD) & $827,6.34(2.03)$ & $527,6.95(1.81)$ & $300,5.27(1.96)$ & $<0.001$ \\
\hline Any AHR (PD20 $\leq 4 \mathrm{mg}), \mathbf{N}$ & 800 & 514 & 286 & \\
\hline
\end{tabular}




\begin{tabular}{|c|c|c|c|c|}
\hline Any AHR (PD20 $\leq 4 \mathrm{mg}), \mathrm{N}(\%)$ & 339 & 138(26.8), & $201(70.3)$ & $<0.001$ \\
\hline High AHR (PD20 $\leq 1 \mathrm{mg}), \mathrm{N}$ & 815 & 523 & 292 & \\
\hline High AHR (PD20 $\leq 1 \mathrm{mg})$, & 67 & $67(12.8)$ & $162(55.5)$ & $<0.001$ \\
\hline \multicolumn{5}{|l|}{$\mathbf{N}(\%)$} \\
\hline Inhaled corticosteroid use, \% & 20.5 & 3.5 & 48.3 & $<0.001$ \\
\hline Blood sampling time, hour & $11.6(2.17)$ & $11.6(2.17)$ & $11.7(2.17)$ & 0.3 \\
\hline \multicolumn{5}{|l|}{ Serum Creatinine, $\mathrm{mg} / \mathrm{dL}$, } \\
\hline Mean (SD) & $0.81(0.16)$ & $0.80(0.17)$ & $0.82(0.16)$ & 0.05 \\
\hline \multicolumn{5}{|l|}{ eGFR, $\mathrm{mL} / \mathrm{min} * 1.73 \mathrm{~m}^{2}$, } \\
\hline Mean (SD) & $100.2(18.8)$ & $98.6(18.8)$ & $102.7(18.5)$ & $<0.001$ \\
\hline CC-16, $\mu \mathrm{g} / \mathrm{L}, \mathrm{GM}$ (SD) & $12.4(1.87)$ & $12.8(1.88)$ & $11.8(1.85)$ & 0.03 \\
\hline
\end{tabular}

AR: Airway responsiveness; AHR: Airway Hyper-responsiveness; CC-16: Club cell secretory protein; $\mathrm{FEV}_{1}$ : forced expiratory volume in 1 second; FVC: forced vital capacity; GFR: Glomerular Filtration Rate; GM: Geometric Mean; $\mathrm{PD}_{20}: 20 \%$ reduction in $\mathrm{FEV}_{1}$ after methacholine challenge test ( $1 \mathrm{mg}$ or $4 \mathrm{mg}$ cumulative dose); SD: Standard Deviation; ${ }^{*}$ Stanojevic reference equations. 
Table 2. Association between participants' characteristics and CC-16 level

\begin{tabular}{|c|c|c|c|c|c|c|}
\hline & \multicolumn{3}{|c|}{ Non asthmatics $(\mathrm{N}=803)$} & \multicolumn{3}{|c|}{ Asthmatics $(\mathrm{N}=495)$} \\
\hline & $\mathrm{N}$ & $\begin{array}{l}\text { CC-16 GM / } \\
\text { Beta }(95 \% \mathrm{CI})^{\dagger}\end{array}$ & Beta $^{\ddagger}$ & $\mathrm{N}$ & $\begin{array}{l}\text { CC-16 GM / } \\
\text { Beta }(95 \% \mathrm{CI})^{\dagger}\end{array}$ & $\mathrm{Beta}^{\ddagger}$ \\
\hline \multicolumn{7}{|l|}{ Sex } \\
\hline Males & 374 & $13.1(12.3,13.9)$ & & 257 & $12.4(11.5,13.3)^{*}$ & \\
\hline Females & 429 & $12.5(11.8,13.3)$ & -0.03 & 238 & $11.2(10.4,12.1)$ & $-0.10^{* *}$ \\
\hline Age, 10 years & & $0.05(0.02,0.08)^{* * *}$ & $-0.05^{* *}$ & & $0.07(0.04,0.10)^{* * *}$ & 0.02 \\
\hline \multicolumn{7}{|l|}{ Smoking status } \\
\hline Lifetime non-smoker & 406 & $13.1(12.3,13.9) * *$ & $-0.04 * *$ & 239 & $11.6(10.7,12.5)^{*}$ & -0.01 \\
\hline Ex smoker, $<15$ pack-years & 179 & $13.8(12.6,15.0)$ & & 102 & $13.3(11.8,15.0)$ & \\
\hline Ex-smoker, $>15$ pack-years & 50 & $12.0(9.78,14.7)$ & & 23 & $13.0(10.2,16.6)$ & \\
\hline Smoker, $<15$ pack-years & 123 & $12.1(10.8,13.6)$ & & 115 & $11.1(9.93,12.5)$ & \\
\hline Smoker, $>15$ pack-years & 39 & $9.34(7.61,11.5)$ & & 12 & $8.99(5.77,14.0)$ & \\
\hline Blood sampling time, hour & 801 & $-0.03(-0.05,-0.008)^{* *}$ & $-0.04 * * *$ & 492 & $-0.04(-0.07,-0.02)^{* * *}$ & $-0.05 * * *$ \\
\hline Serum creatinine, $\mathrm{mg} / \mathrm{dL}$ & 803 & $0.79(0.55,1.03)^{* * *}$ & & 495 & $0.48(0.16,0.79)^{* *}$ & \\
\hline $\begin{array}{l}\text { eGFR estimated, } \\
\mathrm{mL} / \mathrm{min}^{*} 1.73 \mathrm{~m}^{2}\end{array}$ & 803 & $-0.008(-0.01,-0.006)^{* * *}$ & $-0.01 * * *$ & 495 & $-0.006(-0.009,-0.003)^{* * *}$ & $-0.01 * *$ \\
\hline
\end{tabular}


CC-16: Club cell secretory protein; CI: Confidence Interval; eGFR: Glomerural Filtration Rate; GM: Geometric Mean;

${ }^{\dagger}$ Overall P-values for the association between each participant characteristic and CC-16 level

‡ Beta coefficients and p-values from one multivariate regression model with sex, age, smoking status (test for trend), sampling time and glomerular filtration rates as covariates and CC-16 z-score as outcome variable

$* \mathrm{p}<.10, * * \mathrm{p}<.05, * * * \mathrm{p}<.001$ 
Table 3. Association between airway responsiveness and lung function and GFR-standardized CC-16 z-score in participants without asthma

\begin{tabular}{|c|c|c|c|c|c|}
\hline & $\mathbf{N}$ & $\begin{array}{l}\text { Unadjusted beta/ } \\
\text { OR }(95 \% \mathrm{CI})\end{array}$ & $\mathbf{p}$ & $\begin{array}{l}\text { Adjusted beta } \\
\text { /OR }(95 \% \mathrm{CI})\end{array}$ & $\mathbf{p}$ \\
\hline \multicolumn{6}{|l|}{ Lung function measurements } \\
\hline $\mathrm{FEV}_{1} \%$ pred. Values ${ }^{*}, \dagger$ & 791 & $1.15(0.05,2.24)$ & 0.04 & $1.01(-0.07,2.08)$ & 0.07 \\
\hline FVC $\%$ pred. Values ${ }^{*}$, & 791 & $0.57(-0.45,1.60)$ & 0.27 & $0.42(-0.61,1.45)$ & 0.43 \\
\hline $\mathrm{FEV}_{1} / \mathrm{FVC}^{\dagger}$ & 762 & $0.62(0.12,1.12)$ & 0.02 & $0.50(0.06,0.95)$ & 0.02 \\
\hline \multicolumn{6}{|l|}{ Methacholine challenge test, $\mathrm{N}$, } \\
\hline Dose-response slope, Mean (SD) & 527 & $0.25(0.09,0.41)$ & 0.001 & $0.21(0.06,0.37)$ & 0.005 \\
\hline No AHR (reference) & 376 & 1 & & 1 & - \\
\hline Any AR $(\mathrm{PD} 20 \leq 4 \mathrm{mg})^{\ddagger}, \%$ & 138 & $0.83(0.68,1.00)$ & 0.048 & $0.82(0.66,1.02)$ & 0.07 \\
\hline High AR $(\mathrm{PD} 20 \leq 1 \mathrm{mg})^{\ddagger}, \%$ & 67 & $0.70(0.54,0.90)$ & 0.006 & $0.65(0.48,0.87)$ & 0.004 \\
\hline
\end{tabular}

AR: Airway responsiveness; AHR: Airway Hyper-responsiveness; CC-16: Club cell secretory protein; CI: Confidence Interval; FEV 1 : forced expiratory volume in 1 second; FVC: Forced Vital Capacity; GFR: Glomerular Filtration Rate; OR: Odds Ratios; $\mathrm{PD}_{20}$ : 20\% reduction in $\mathrm{FEV}_{1}$ after methacholine challenge test (1 mg or $4 \mathrm{mg}$ cumulative dose); SD: Standard Deviation;

* $\mathrm{FEV}_{1} \%$ predicted and $\mathrm{FVC} \%$ predicted ranged from 0 to 1 and were obtained using Stanojevic reference equations ${ }^{40}$.

${ }^{\dagger}$ Beta estimates $(95 \% \mathrm{CI})$ for a unitary increase in the GRF adjusted CC-16 z-score, estimated with GEE linear regression models 
${ }^{\ddagger}$ Odds ratios $(95 \% \mathrm{CI})$ for a unitary increase in the GRF adjusted CC-16 z-score, estimated with GEE logistic regressions models

All estimates are reported as unadjusted and adjusted for age, smoking status and pack-years (never smokers, ex-smokers that smoked $\leq 15$ pack-years, ex-smokers that smoked $\geq 15$ pack-years, current smokers with $<15$ pack-years and current smokers with $\geq 15$ pack-years), blood sampling time, sex (for $\mathrm{FEV}_{1} / \mathrm{FVC}$, any and high $\mathrm{AHR}$ and $\mathrm{AR}$ ) and height (for $\mathrm{FEV}_{1} / \mathrm{FVC}$ ) 
Figure 1. Flow chart of the EGEA population and the participants included in the study

Figure 2. CC-16 according to the dose-response slope by asthmatic status

Legend: CC-16 GM level by dose-response slope (grouped in quartiles. The p-values refer to test for trend among participants who did perform the methacholine challenge test. The first bar in each group is related to participants who did not perform the test because of baseline $\mathrm{FEV}_{1}<80 \%$ predicted or $\mathrm{FEV}_{1}$ post dilution $<90 \%$ of the baseline $\mathrm{FEV}_{1}$ 
Serum CC-16 level is associated with asymptomatic Airway responsiveness in adults from the EGEA study

\section{SUPPLEMENTAL DATA}

\section{METHODS}

\section{Population and protocol}

The EGEA combines a case-control and family study of adult and childhood asthma (http://egeaintranet.vjf.inserm.fr/). The first EGEA survey (EGEA1) was conducted from 1991 to 1995, and the protocol and descriptive characteristics have been described elsewhere ${ }^{1}$. Briefly, 388 asthmatic cases, recruited in 5 chest clinics, 1244 first-degree relatives of cases, and 415 population-based controls were recruited (total, $n=2047$ ). A 12-year follow-up of this population was conducted from 2003 to 2007 (EGEA2) in 5 centres in France (Grenoble, Paris, Lyon, Marseille, Montpellier). Participants were contacted by postal questionnaire, and non-responders were further contacted by telephone (step 1). Among the alive cohort $(n=2002), 92 \%(n=1845)$ completed the short self-questionnaire. Responders were invited to participate in the second phase of the study (step 2). The complete examination was mostly performed in clinical centers $(\mathrm{n}=1316$; $85.3 \%$ ). However, to improve the follow-up rate, some participants were examined at home $(\mathrm{n}=72$; $4.7 \%)$ or answered questionnaires by phone $(n=78 ; 5.0 \%)$ or mail $(n=77 ; 5.0 \%)$. Finally, $77 \%$ of the alive cohort $(n=1543)$ completed at least a detailed questionnaire. In addition, 58 new family members where included in the study at the second survey. Written consent was obtained from all participants at both surveys. Ethical approval to carry out the study was obtained for both surveys from the relevant committees (Cochin Royal Hospital, Paris, for EGEA1, and Necker-Enfants Malades Hospital, Paris, for EGEA2). Examination procedures included a detailed questionnaire, with questions on asthma and respiratory symptoms, treatment, allergic rhinitis, active smoking, and exposure to environmental tobacco smoke. Participants had blood samples that allowed to measure total IgE in a centralized laboratory $(n=1421 ; 88.8 \%)$. Spirometry was performed by using a standardized protocol with similar equipment across centers according to the American Thoracic Society / European Respiratory Society guidelines ${ }^{2}$ to measure $\mathrm{FEV}_{1}(\mathrm{n}=1414 ; 88.3 \%)$. Skin prick tests to 12 aeroallergens (cat, Dermatophagoides pteronyssinus, Blattela germanica, olive, birch, Parieteria judaica, timothy grass, ragweed pollen, Aspergillus, Cladospo- rium herbarum, Alternaria tenuis, Cypress) were performed in 1326 participants (82.8\%). Sensitization was defined by the presence of at least 1 positive skin test (mean wheal diameter $\geq 3 \mathrm{~mm}$ ). Strong efforts were made to standardize all the examination procedures across centers and to minimize missing data. A 
quality management approach was followed for the implementation of the EGEA2 data collection, and an International Organization for Standardization (ISO) 9001:2000 certification was obtained (http://www.afaq.org/certification5262711141114).

\section{Phenotype definitions}

Inhaled corticosteroid use was defined by a positive answer to the question, "Have you used inhaled corticosteroids to help your breathing at any time in the past year?', with an exhaustive list of medications available in France at the time of the study.

Participants were defined with (1) controlled asthma if all the following features were present: no more than 1 instance per week of trouble breathing (defined by the answer to "How often have you had trouble with your breathing because of your asthma in the past 3 months?') and no asthma attack in the last 3 months (defined by the answer to "How many asthma attacks have you had in the past 3 months?'), no nocturnal symptoms (woken up because of asthma or by an attack of shortness of breath) in the last 3 months, use of short-acting $\beta 2$-agonist inhalers $\leq 2 /$ wk in the last 3 months, no use of oral corticosteroids in the past year, $\mathrm{FEV}_{1} \geq 80 \%$ predicted; (2) partly controlled asthma if 1 or 2 of these features were absent; and (3) uncontrolled asthma if $\geq 3$ of these features were absent or if respiratory problems had caused hospital or emergency admissions in the past year or use of oral corticosteroids in the past year or $\geq 12$ asthma attacks in the past 3 months.

\section{Biological phenotypes}

Serum CC-16 level was determined with latex immunoassay using a rabbit anti-CC-16 antibody (Dakopatts, Glostrup, Denmark) and purified CC-16 protein as standards (home made at the Laboratory of Toxicology Applied Pharmacology, Faculty of Medicine, Catholic University of Louvain, Belgium). When pooled normal sera is fractionated by fast protein liquid chromatography on Sephacryl S-200 (Pharmacia Biotechnology, Uppsala, Sweden), CC-16 elutes as a single component with an apparent $\mathrm{M}_{\mathrm{r}}$ of $\sim 16 \mathrm{kD}$, and is indistinguishable from the native protein. To avoid possible interference by complement, rheumatoid factor, or chylomicrons, the plasma samples were pretreated by heating at $56^{\circ} \mathrm{C}$ for $30 \mathrm{~min}$ and by the addition of polyethylene glycol $(16 \%, 1: 1[\mathrm{vol} / \mathrm{vol}]$ and trichloroacetic acid $(10 \%, 1: 40$ [vol/vol]). After overnight precipitation at $4^{\circ} \mathrm{C}$, the samples were centrifuged $(2,000 \mathrm{x}$ g for $10 \mathrm{~min})$ and $\mathrm{CC}-16$ was determined in the supernatants. All samples were analyzed in duplicate at two different dilutions. The assay has a detection limit of $0.5 \mathrm{ng} / \mathrm{ml}$ and an average analytical recovery of $95 \%$, with the intra- and interassay coefficients of variation ranging from 5 to $10 \%^{3}$. Serum creatinine was determined with standard traceable IDMS (isotope dilution mass spectrometry traceable) assay. 
Glomerular filtration rate (eGFR) was estimated using the CKD-EPI (Chronic Kidney Disease Epidemiology Collaboration) formula ${ }^{4}$ (see below) and expressed as $\mathrm{mL} / \mathrm{min}^{*} 1.73 \mathrm{~m}^{2}$ :

$\mathrm{eGFR}=141 \mathrm{X} \min (\mathrm{Scr} / \kappa, 1)^{\alpha} \mathrm{X} \max (\mathrm{Scr} / \kappa, 1)^{-1.209} \mathrm{X} 0.993^{\text {Age }} \mathrm{X} 1.018$ [if female] X 1.159 [if black], where Scr is the serum creatinine level $(\mathrm{mg} / \mathrm{dL}), \kappa=0.7$, if female or 0.9 if males, $\alpha=0.329$, if females, or -0.411 , if males

\section{RESULTS}

\section{Characteristics of the sample}

Participants with asthma were younger and smoked less frequently than participants without asthma. Lung function parameters were lower and $\mathrm{AHR}\left(\mathrm{PD}_{20} \leq 4 \mathrm{mg}\right)$ was more frequent in participants with asthma than in those without asthma.

Among participants who performed the methacholine test $(\mathrm{N}=862), 800$ (514 with asthma and 286 without) had information about their reduction in FEV1 after a provocative dose of methacholine of 4mg (PD20<4mg). 339 out of $800(42.4 \%)$ had PD20<4mg and among those 138 (138/514=26.8) were without asthma and $201(201 / 286=70.3)$ were with asthma. For what concern PD20<1mg, data were available for 815 participants (523 without asthma and 292 with asthma). Among those, 67 (12.8) with asthma and 162 (55.4) controls reported PD20<1mg.

Participants who performed the methacholine test were more often females $(54 \%$ vs. $45 \%$, $\mathrm{p}=0.007)$, were younger (mean age $=41$ vs. 50 years, $\mathrm{p}<0.001)$, smoked more frequently $(24.3 \% v s$. $19.6 \%, \mathrm{p}=0.06$ ), had higher level of eGFR (mean value: 103 vs. $95 \mathrm{~mL} / \mathrm{min} * 1.73 \mathrm{~m}^{2}, \mathrm{p}<0.001$, age and sex adjusted $\mathrm{p}<0.001$ ) and higher $\mathrm{FEV}_{1}$ (mean value: 3.5 vs. $2.9 \mathrm{~L}, \mathrm{p}<0.001$, age and sex adjusted $\mathrm{p}<0.001)$ than participants who $\operatorname{did} \operatorname{not}(\mathrm{N}=416)$.

Table E1. Association between asthma, airway responsiveness and lung function and GFRstandardized CC-16 z-score in participants with asthma

$\begin{array}{llll}\mathrm{N} \quad \text { Unadjusted beta/ } & \mathrm{p} & \text { Adjusted beta } & \mathrm{p} \\ \mathrm{OR}(95 \% \mathrm{CI}) & & / \mathrm{OR}(95 \% \mathrm{CI}) & \end{array}$

\section{Lung function measurements}

$\begin{array}{lccccc}\text { FEV }_{1} \text { \% predicted*,a } & 791 & 1.53(-0.21,3.27) & 0.09 & 1.53(-0.21,3.27) & 0.19 \\ \text { FVC \% predicted }^{*, a} & 791 & 0.44(-0.82,1.71) & 0.49 & 0.44(-0.82,1.71) & 0.67 \\ \text { FEV1/FVC } & 762 & 0.86(-0.28,2.00) & 0.14 & 0.86(-0.28,2.00) & 0.15\end{array}$

Methacholine challenge test, $\mathbf{N}$ 


\begin{tabular}{|c|c|c|c|c|c|}
\hline Dose-response slope $^{\mathrm{a}}$ & 300 & $0.05(-0.16,0.26)$ & 0.63 & $0.08(-0.13,0.30)$ & 0.45 \\
\hline No AHR (ref) & 85 & & & & \\
\hline Any AHR (PD20 $\leq 4 m g)^{b}, \%$ & 201 & $1.04(0.78,1.39)$ & 0.77 & $0.99(0.72,1.36)$ & 0.97 \\
\hline High AHR (PD20 $\leq 1 \mathrm{mg})^{\mathrm{b}}, \%$ & 162 & $1.06(0.82,1.36)$ & 0.65 & $1.07(0.81,1.41)$ & 0.62 \\
\hline
\end{tabular}

AR: Airway responsiveness; AHR: Airway Hyper-responsiveness; CC-16: Club cell secretory protein; CI: Confidence Interval; $\mathrm{FEV}_{1}$ : forced expiratory volume in 1 second; FVC: Forced Vital Capacity; GFR: Glomerural Filtration Rate; GM: Geometric Mean; OR: Odds Ratios; PD $20: 20 \%$ reduction in $\mathrm{FEV}_{1}$ after methacholine challenge test ( $1 \mathrm{mg}$ or $4 \mathrm{mg}$ cumulative dose); SD: Standard Deviation;

* FEV $1 \%$ predicted and FVC\% predicted ranged from 0 to 1 and were obtained using Quanjer reference equations

${ }^{\text {a }}$ Beta estimates $(95 \% \mathrm{CI})$ for a unitary increase in the GRF adjusted CC-16 z-score, estimated with GEE linear regression models

${ }^{\mathrm{b}}$ Odds ratios $(95 \% \mathrm{CI})$ for a unitary increase in the GRF adjusted CC-16 z-score, estimated with GEE logistic regressions models

All estimates are reported as unadjusted and adjusted for age, smoking status and pack-years (never smokers, ex-smokers that smoked $\leq 15$ pack-years, ex-smokers that smoked $\geq 15$ pack-years, current smokers with $<15$ pack-years and current smokers with $\geq 15$ pack-years), blood sampling time, sex (for $\mathrm{FEV}_{1} / \mathrm{FVC}$, any and high $\mathrm{AHR}$ and $\mathrm{AR}$ ) and height (for $\mathrm{FEV}_{1} / \mathrm{FVC}$ ) 
Figure E1. Association between lung function, AR and GFR-standardized CC-16 z-score grouped in quartiles in participants without asthma 
Legend: prevalence of AHR and degree of AR by quartiles of CC-16 z-score. Asterisks represent P-values obtained by comparing the odds ratio of
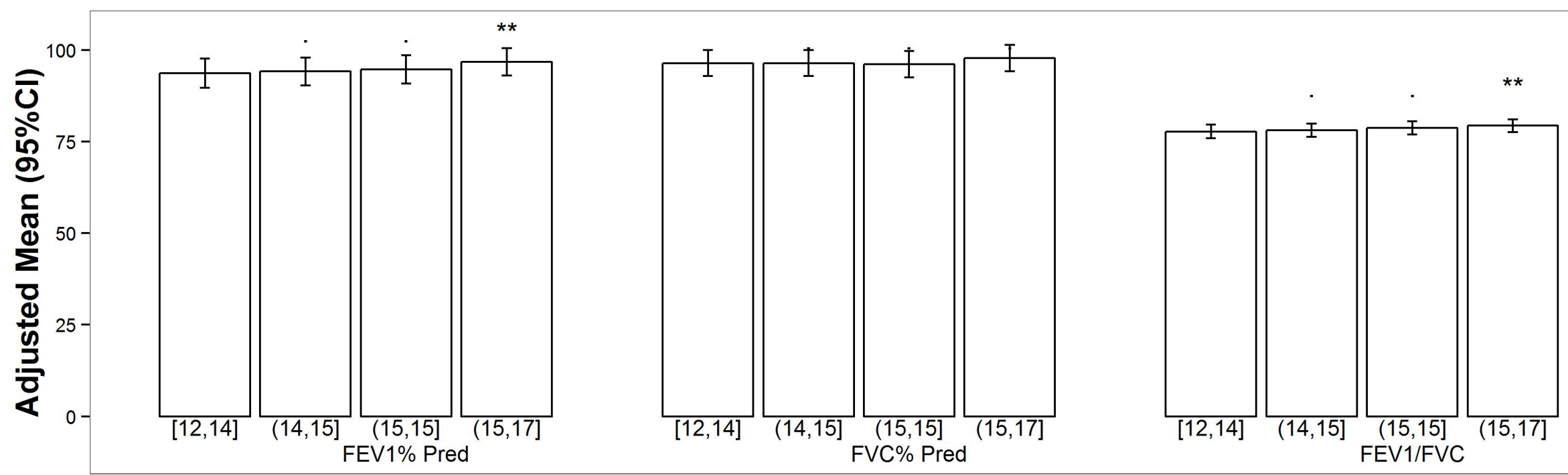

\section{Lung function parameters}
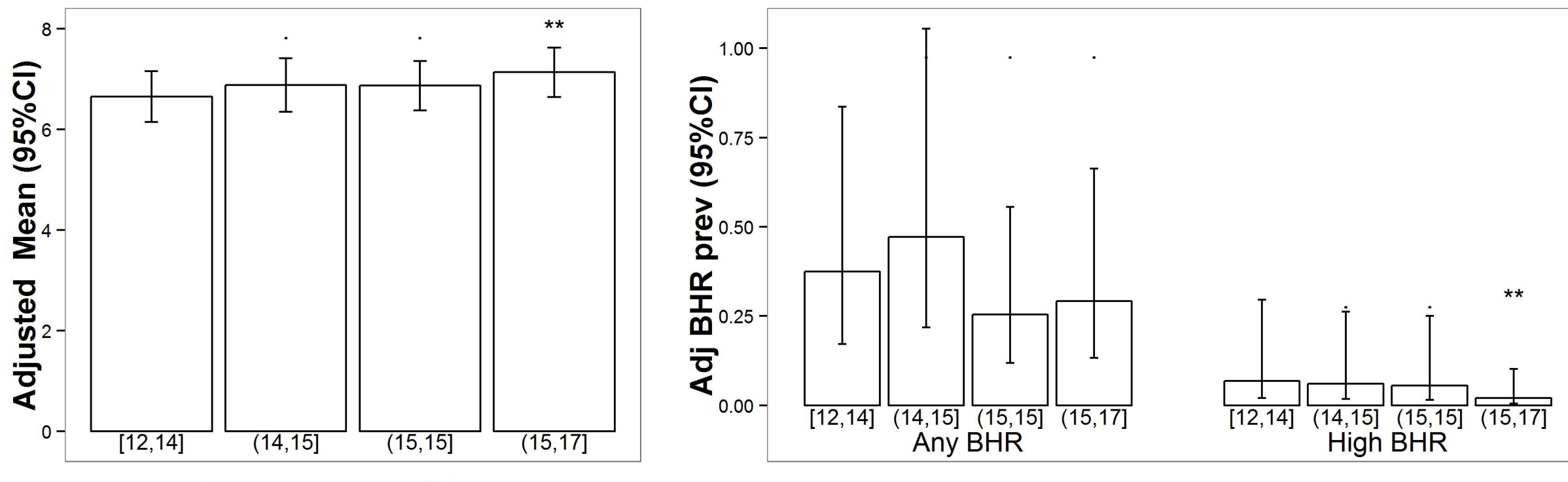

nnen mennnmen Clann 
having AHR (Any AHR $\left(\mathrm{PD}_{20} \leq 4 \mathrm{mg}\right.$ ) or High AHR ( $\left.\mathrm{PD}_{20} \leq 1 \mathrm{mg}\right)$ ) or the average degree of $\mathrm{AR}$, for each quartile of CC-16 z-score, using the first quartile as reference, after adjustment for blood sampling time, sex, age and smoking status. $((*) \mathrm{P}<0.10,(* *) \mathrm{P}<0.05,(* * *) \mathrm{P}<.001)$.

\section{OLD VERSION TO BE DELETED}

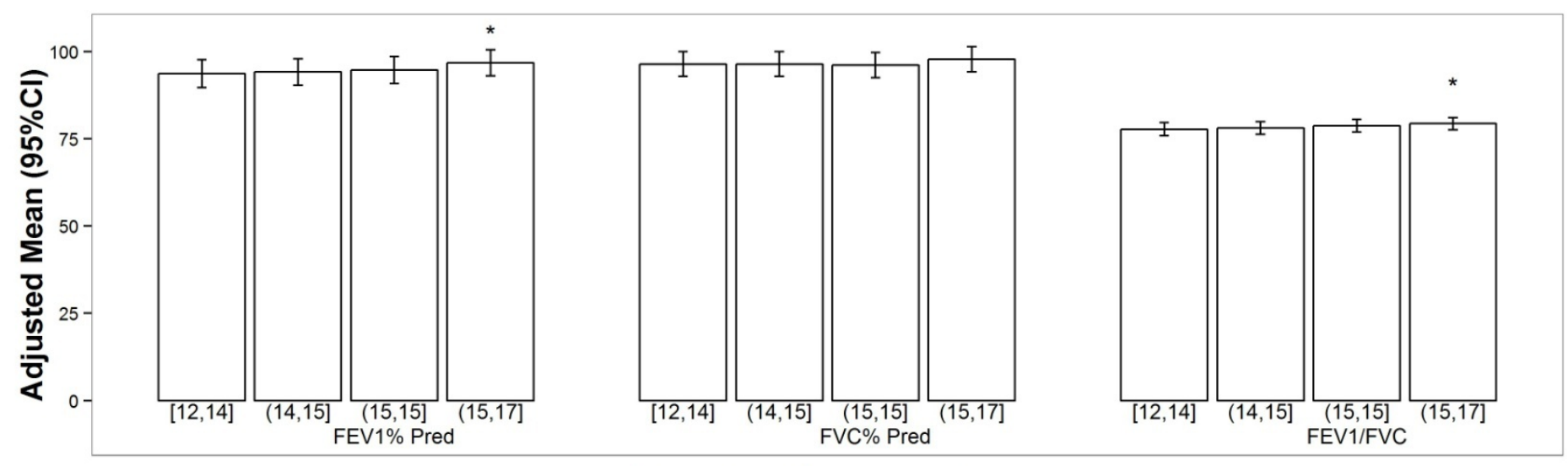

\section{Lung function parameters}
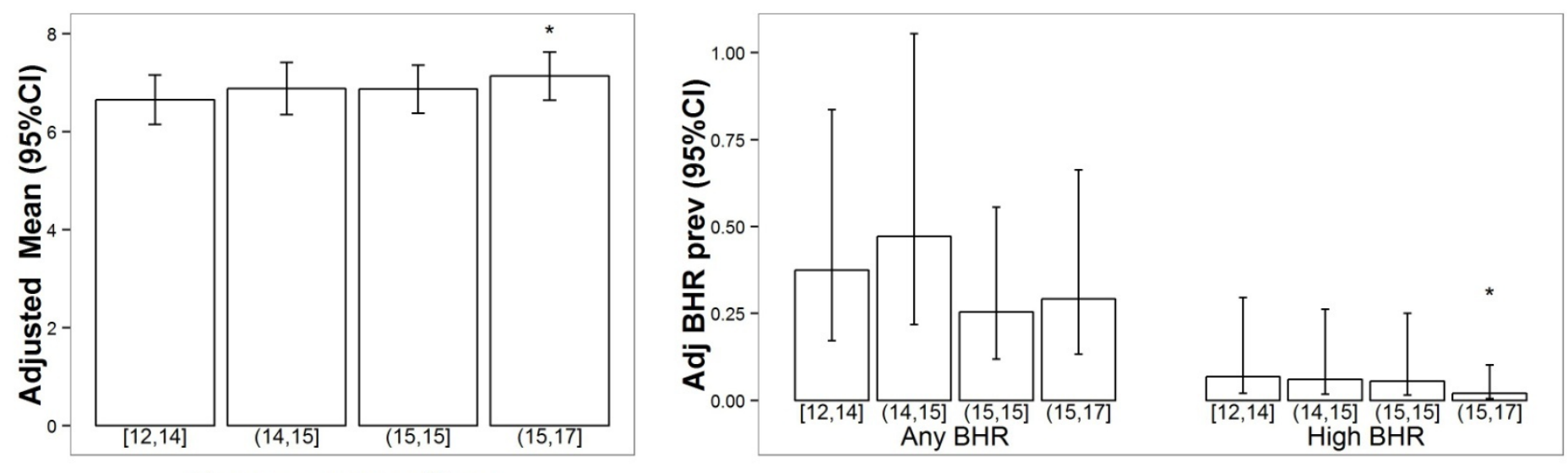

Dose-response Slope 
Figure E2. Association between the dose-response slope and lung function and GFRstandardized CC-16 z-score stratified by smoking status in non- asthmatic participants.
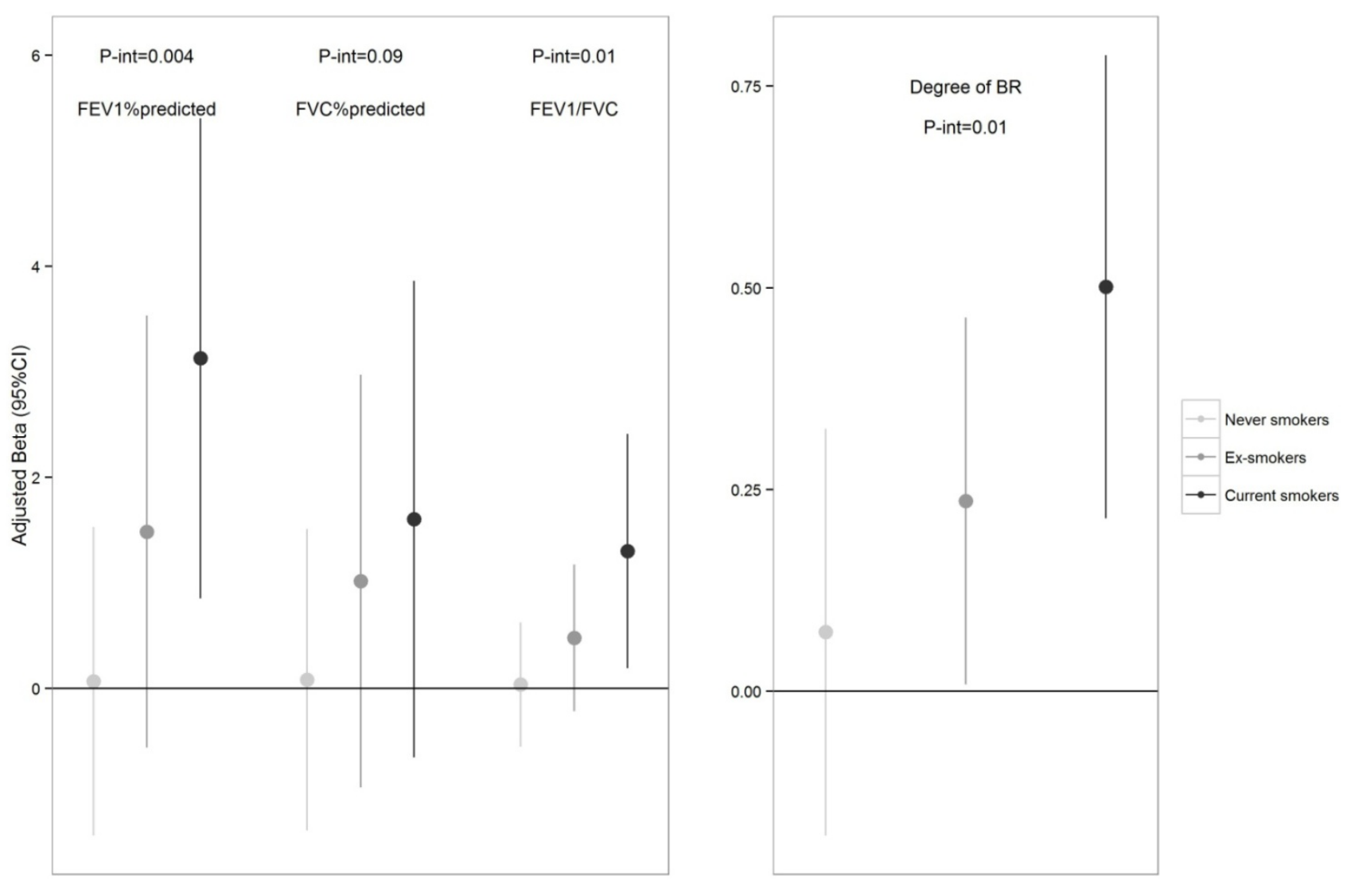

Legend: regression coefficients (Beta) and 95\%CI for the association between CC-16 zscore and Airway responsiveness, estimated through GEE logistic and linear models, stratified by smoking status and adjusted by age, sex and sampling time and height (for FEV1/FVC). The P-values refer to the interaction between smoking status and the CC-16 zscores. 


\section{References}

1. Siroux V, Boudier A, Bousquet J, Bresson J-L, Cracowski J-L, Ferran J, et al. Phenotypic determinants of uncontrolled asthma. J Allergy Clin Immunol 2009;124:681-7.e3.

2. Miller MR, Hankinson J, Brusasco V, Burgo F, Casaburi R, Coates A, et al. Standardisation of spirometry. Rev Mal Respir 2007;24:2S27-S49.

3. Bernard A, Marchandise FX, Depelchin S, Lauwerys R, Sibille Y. Clara cell protein in serum and bronchoalveolar lavage. Eur Respir J Off J Eur Soc Clin Respir Physiol 1992;5:1231-8.

4. Stevens LA, Schmid CH, Greene T, Zhang YL, Beck GJ, Froissart M, et al. Comparative performance of the CKD Epidemiology Collaboration (CKD-EPI) and the Modification of Diet in Renal Disease (MDRD) Study equations for estimating GFR levels above $60 \mathrm{~mL} / \mathrm{min} / 1.73 \mathrm{~m} 2$. Am J Kidney Dis 2010;56:486-95. 